\title{
Measurement Uncertainty of Silicone Fluid Leakage Testing for Rolamites
}

Federal Manufacturing \& Technologies

W. E. Holland

mAY 131937

KCP-613-5908

Published April 1997

Approved for public release; distribution is unlimited.

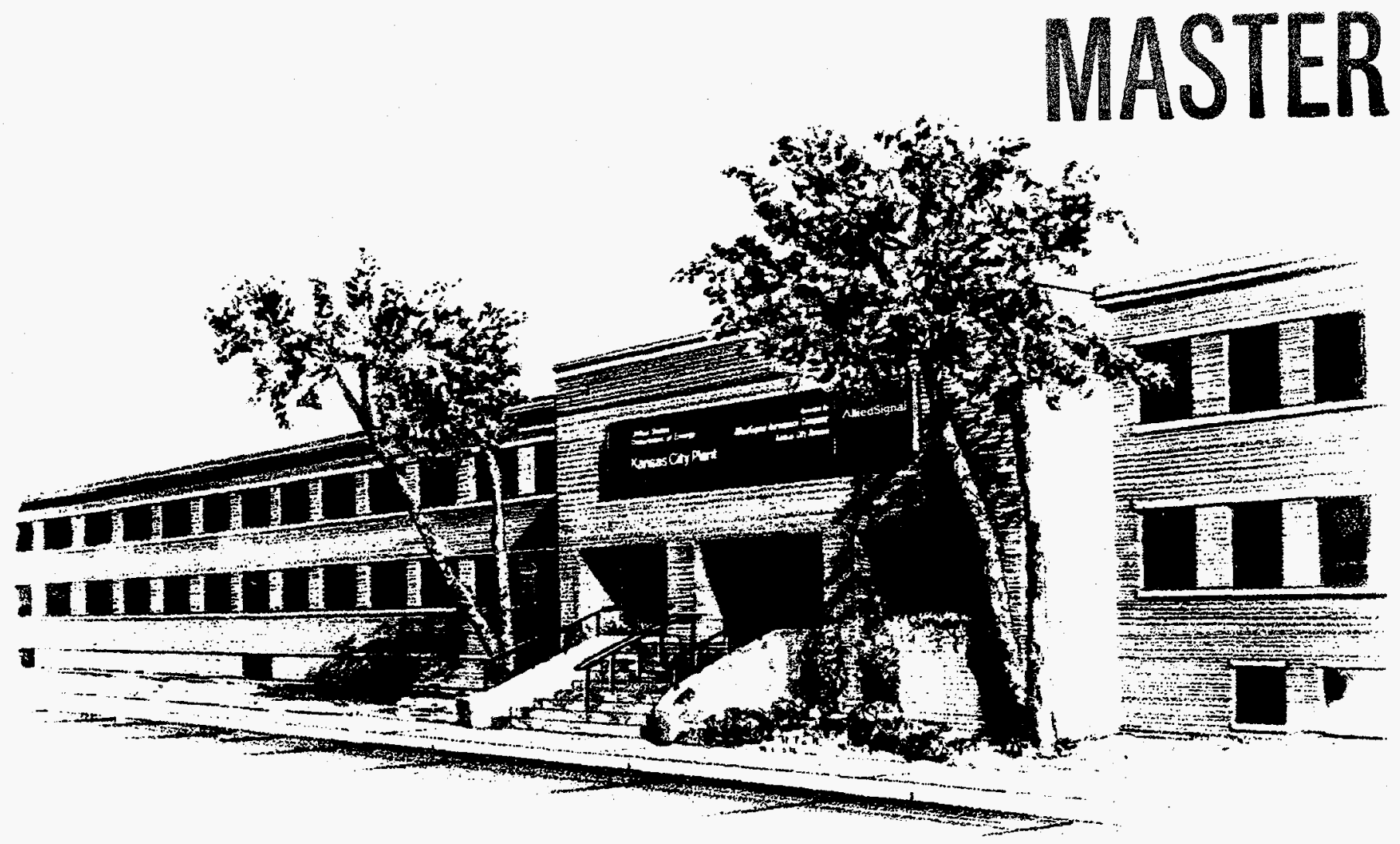

Prepared Under Contract Number DE-ACO4-76-DP00613 for the 


\section{DISCLAIMER}

This report was prepared as an account of work sponsored by an agency of the United States Government. Neither the United States Government nor any agency thereof, nor any of their employees, makes any warranty, express or implied, or assumes any legal liability or responsibility for the accuracy, completeness, or usefulness of any information, apparatus, product, or process disclosed, or represents that its use would not infringe privately owned rights. Reference herein to any specific commercial product, process, or service by trade names, trademark, manufacturer, or otherwise, does not necessarily constitute or imply its endorsement, recommendation, or favoring by the United States Government or any agency thereof. The views and opinions of authors expressed herein do not necessarily state or reflect those of the United States Government or any agency thereof.

Printed in the United States of America.

This report has been reproduced from the best available copy.

Available to DOE and DOE contractors from the Office of Scientific and Technical Information, P. O. Box 62, Oak Ridge, Tennessee 37831; prices available from (615) 576-8401, FTS 626-8401.

Available to the public from the National Technical Information Service, U. S. Department of Commerce, 5285 Port Royal Rd., Springfield, Virginia 22161.

A prime contractor with the United States Department of Energy under Contract Number DE-ACO4-76-DP00613.
AlliedSignal Inc. Federal Manufacturing \& Technologies P. O. Box 419159 Kansas City, Missouri 64141-6159 


\section{DISCLAIMER}

This report was prepared as an account of work sponsored by an agency of the United States Government. Neither the United States Government nor any agency thereof, nor any of their employees, make any warranty, express or implied, or assumes any legal liability or responsibility for the accuracy, completeness, or usefulness of any information, apparatus, product, or process disclosed, or represents that its use would not infringe privately owned rights. Reference herein to any specific commercial product, process, or service by trade name, trademark, manufacturer, or otherwise does not necessarily constitute or imply its endorsement, recommendation, or favoring by the United States Government or any agency thereof. The views and opinions of authors expressed herein do not necessarily state or reflect those of the United States Government or any agency thereof. 


\section{DISCLAMMER}

Portions of this document may be illegible in electronic image produets. Images are produced from the best available original document. 
KCP-613-5908

Distribution Category UC-706

Approved for public release; distribution is unlimited.

\author{
MEASUREMENT UNCERTAINTY \\ OF SILICONE FLUID LEAKAGE TESTING FOR ROLAMITES \\ W. E. Holland \\ Published April 1997 \\ W. E. Holland, Project Leader
}

DISTRIBUTION OF THIS BOQUMENF IS UNLIMITES

AlliedSignal

A E R O S P A C E 


\section{Contents}

Section

Abstract.

Summary

Discussion

Scope and Purpose

Activity

The Testing Process

Mathematical Simulation

Proposed Tolerances

Total Uncertainty of the Process.

Accomplishments.

Appendices

A. Uncertainty Summary .............................................................. $\quad 8$

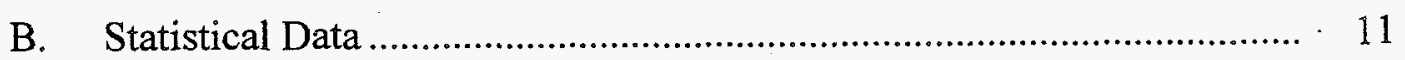

C. Rolamite and Unit Handling Frame Volumes and Their Uncertainties

D. Measurement of Sample Loop Volume and Evacuated Tube Volume 


\section{Illustration}

Figure Page

1 Silicone Fluid Measurement Volumes.................................................. 3

\section{Table}

Number Page

1 Proposed Tolerances for Measurement Volumes .................................... 6 


\begin{abstract}
An evaluation has been performed to determine the uncertainty of silicone fluid leakage measurements for two rolamites. The units are tested with a gas chromatograph, an instrument which can measure silicone fluid vapor by the gas chromatography method. An analysis has shown that the portion of the measurement uncertainty resulting from the uncertainties of the volumes used in the procedure can be maintained at $\pm 18 \%$ when the volumes are held to a given set of tolerances.
\end{abstract}

\title{
Summary
}

A mathematical simulation of the silicone fluid leak testing procedures for two rolamites showed that the leak rate criterion could be modeled by a simple equation involving five volumes that required control (certification). An uncertainty source evaluation was implemented to list and quantify random and systematic uncertainty sources for each volume. A set of practical tolerances for the volumes was recommended, and the portion of the measurement uncertainty resulting from the uncertainties of the volumes was calculated. 


\section{Discussion}

\section{Scope and Purpose}

Metrology at AlliedSignal Federal Manufacturing \& Technologies (FM\&T) has been requested to evaluate the uncertainty involved in silicone oil leak testing. This was a portion of the work performed by a Total Quality team organized to identify the volumes required for the testing, to determine the leak rate criteria for the testing process, and to reduce the process uncertainty to a minimum.

Silicone oil is added to two rolamites as a damping material. It is necessary to test for leakage because leaking oil could contaminate other weapon components.

The silicone oil is a mixture of $20.0 \mathrm{cS}$ silicone fluid, $1.0 \mathrm{cS}$ silicone fluid, and triethylene glycol dimethyl ether. Silicone oil in rolamite A contains $25.6 \%$ by weight of the $1.0 \mathrm{cS}$ silicone fluid, and the oil in rolamite B contains $41.4 \%$ by weight of the $1.0 \mathrm{cS}$ silicone fluid. Only the $1.0 \mathrm{cS}$ fluid is measured by the leak testing process, so that the leak rate specification refers only to the $1.0 \mathrm{cS}$ silicone fluid.

\section{Activity}

\section{The Testing Process}

Leak testing procedures for two units are described in internal procedures. The units are loaded into containers called "test fixtures," and the test fixtures are then heated to $75^{\circ} \mathrm{C}$. After the test fixture has been heated for 2 hours minimum, a small sample of gas is removed and tested for $1.0 \mathrm{cS}$ fluid vapor using a gas chromatograph.

Standardization of the gas chromatograph is accomplished by preparing a "known" sample of the $1.0 \mathrm{cS}$ silicone fluid vapor in a test chamber assembly and comparing the response of the gas chromatograph when injecting the known amount and the test sample. The test chamber assemblies used for preparing the known samples are called "reference" fixtures.

The known sample is prepared in several steps as shown in Figure 1. First, $3 \mu \mathrm{L}$ of $1.0 \mathrm{cS}$ silicone fluid are measured with a $5-\mu \mathrm{L}$ syringe and injected into a clean nitrogen-filled $21410-\mathrm{mL}$ flask. The flask is then agitated to vaporize the fluid, and the vapor is allowed to stabilize. Next, approximately $1 \mathrm{~mL}$ of silicone fluid vapor is withdrawn from the flask using a gas-tight $1-\mathrm{mL}$ syringe. The plunger of the syringe is retracted to the stop so that a repeatable amount can be extracted. The vapor in the syringe is injected into a sealed, evacuated reference fixture, and then the reference fixture is filled with air zero up to atmospheric pressure and stored at $75^{\circ} \mathrm{C}$ for a minimum of one hour. The known sample is now ready to be introduced into the sampler of the gas chromatograph. 

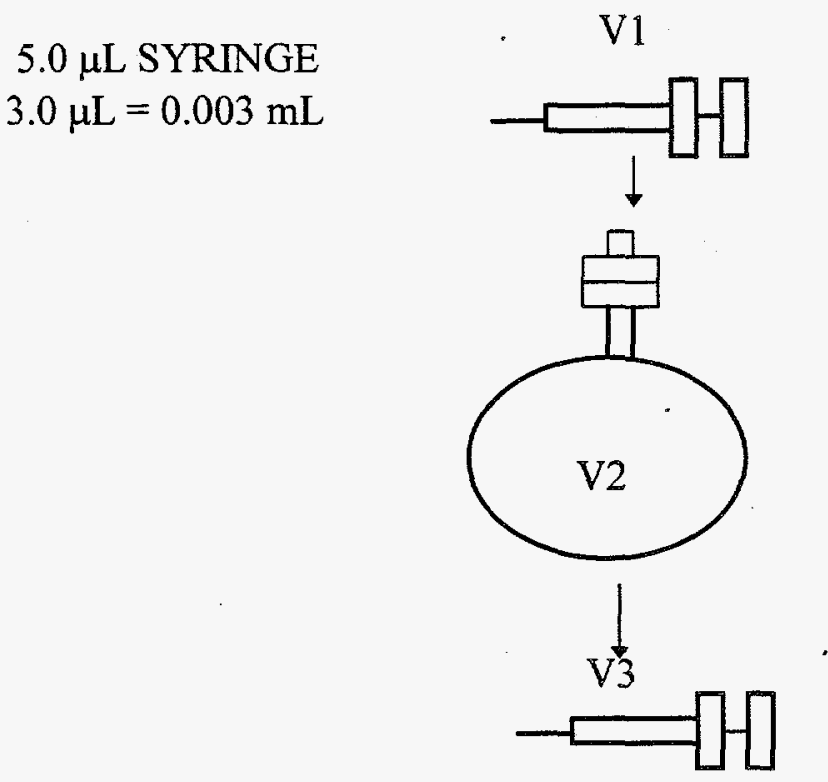

\section{REFERENCE FLASK}

$21410 \mathrm{~mL}$

$1.0 \mathrm{~mL}$ SYRINGE

$1.0 \mathrm{~mL}$

UNIT HANDLING

ROLAMITES

FRAME $0.14 \mathrm{~mL}$

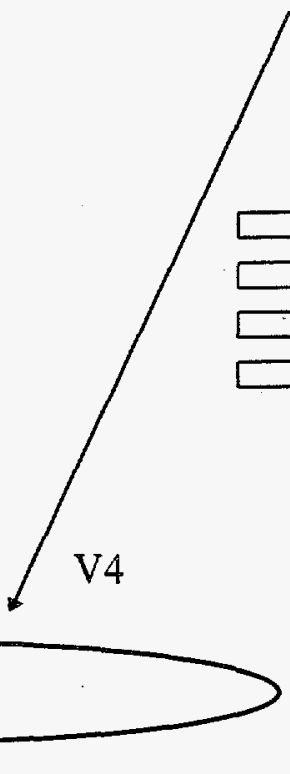

REFERENCE FIXTURE $141.5 \mathrm{~mL}$

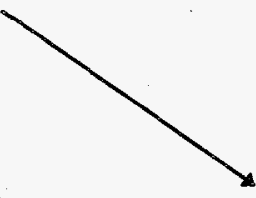

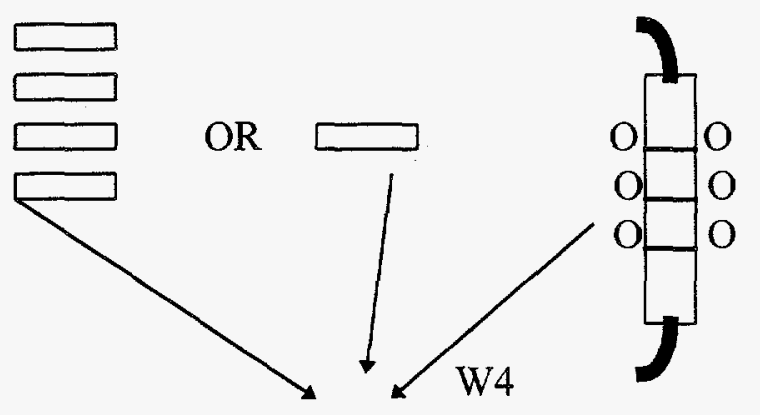

EVACUATED

TUBES

$4.2 \mathrm{~mL}$
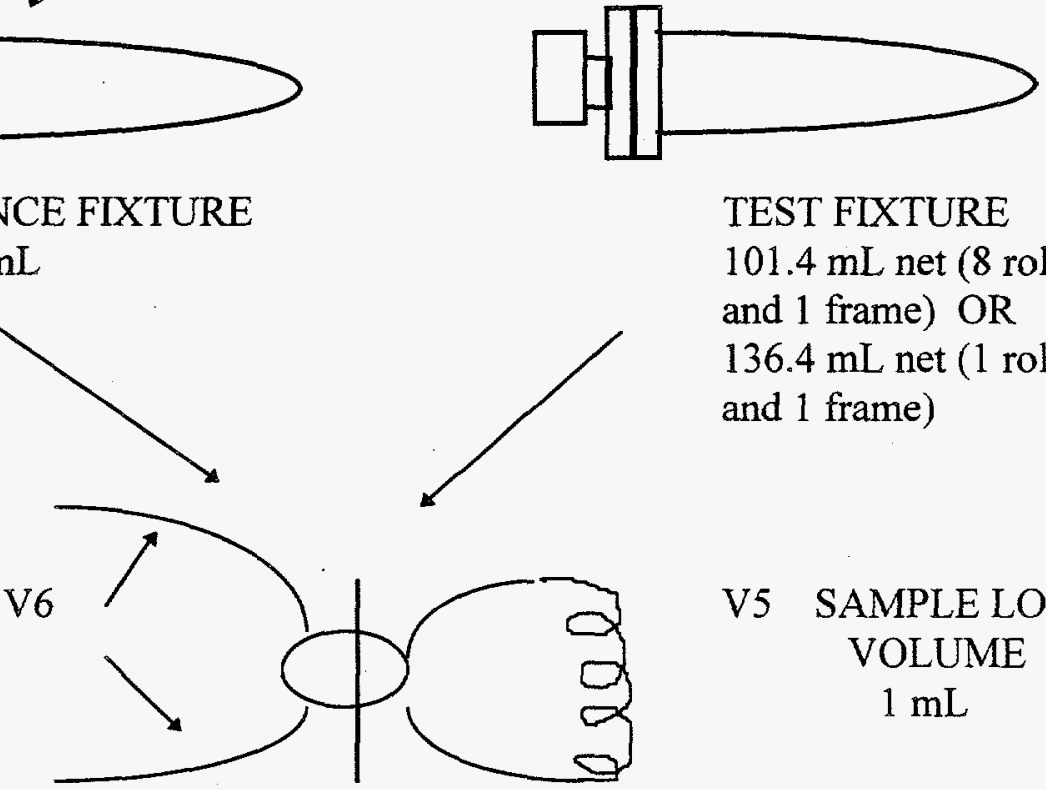

TEST FIXTURE

$101.4 \mathrm{~mL}$ net $(8$ rolamites and 1 frame) $\mathrm{OR}$

$136.4 \mathrm{~mL}$ net (1 rolamite and 1 frame)

\section{V5 SAMPLE LOOP VOLUME $1 \mathrm{~mL}$}

Figure 1. Silicone Fluid Measurement Volumes 
The sampler of the gas chromatograph is evacuated before a sample is drawn from a fixture containing either the known sample or the parts to be tested. After the fixture is connected, the pressures in the fixture and the sampler are allowed to equilibrate, and then the fixture is removed. However, only a portion of the amount drawn into the sampler--the amount in the sample loop--is flushed into the gas chromatograph.

\section{Mathematical Simulation}

Symbols used in the mathematical analysis of uncertainty are defined below. Refer to Figure 1 for additional explanation.

$\mathrm{V} 1=$ Volume dispensed by the $5.0-\mu \mathrm{L}$ syringe from the $3.0-\mu \mathrm{L}$ mark.

$\mathrm{V} 2=$ Volume of the $21410-\mathrm{mL}$ flask minus volume of 96 beads $(6.35 \mathrm{~mm}$ dia. $)$.

$\mathrm{V} 3=$ Volume of the $1-\mathrm{mL}$ syringe at the stop (approximately $1.07 \mathrm{~mL}$ ).

$\mathrm{V} 4=$ Volume of the reference fixture.

W4 = Volume of the test fixture (volume of the test chamber assembly minus volume of the unit handling frame and the rolamites.)

V5 $=$ Volume of the sample loop.

V6 $=$ Volume in evacuated lines (exclusive of sample loop)

Then the concentration of silicone fluid in the flask is

$\mathrm{C} 2=$ Concentration in flask $=\mathrm{V} 1 / \mathrm{V} 2$,

and the concentration in the reference fixture is

$\mathrm{C} 4=$ Concentration in reference fixture $=\mathrm{V} 3(\mathrm{C} 2) / \mathrm{V} 4$

$$
\begin{aligned}
& =\mathrm{V} 3(\mathrm{~V} 1 / \mathrm{V} 2) / \mathrm{V} 4 \\
& =\frac{V 1 \bullet V 3}{V 2 \bullet V 4}
\end{aligned}
$$

The volume of silicone fluid A introduced into the sample loop from the reference fixture is

$A=V 5 \frac{(V 1 \bullet V 3)}{V 2(V 4+V 5+V 6)}$

Here the term V4 + V5 + V6 has been used in the denominator because the concentration is changed slightly when the volume V5 + V6 is added to the volume containing the silicone fluid while the sample loop is being filled. 
Next, it is necessary to find an equation for the volume $\mathrm{S}$ of silicone fluid in the sample loop when a volume $\mathrm{X}$ of $1.0 \mathrm{cS}$ silicone fluid is leaked into the test fixture $\mathrm{W} 4$. By comparison to the above equation, the volume $S$ is

$$
S=V 5\left(\frac{X}{W 4+V 5+V 6}\right)
$$

where,

$\mathrm{X}=$ Volume of $1.0 \mathrm{cS}$ silicone fluid leaked from rolamites into test fixture

$$
=\text { leak rate } \mathrm{x} \text { time }=\mathrm{R} \cdot \mathrm{T} \text {, }
$$

or

$$
S=V 5 \frac{X}{(W 4+V 5+V 6)}=V 5 \frac{R \bullet T}{(W 4+V 5+V 6)}
$$

The criterion for switch acceptance is $\mathrm{S} \leq \mathrm{A}$

or

$$
\frac{V 5 \bullet R \bullet T}{(W 4+V 5+V 6)} \leq \frac{V 1 \bullet V 3 \bullet V 5}{V 2(V 4+V 5+V 6)}
$$

This criterion can be expressed in terms of the leak rate as

$$
R \leq \frac{V 1 \bullet V 3 \bullet V 5}{V 2(V 4+V 5+V 6)} \frac{(W 4+V 5+V 6)}{V 5 \bullet T}=\frac{V 1 \bullet V 3}{V 2 \bullet T} \frac{(W 4+V 5+V 6)}{(V 4+V 5+V 6)}
$$

The uncertainty in the leak rate measurement can be specified if the uncertainty in V1, V2, V3, V4, W4, and T can be determined. It is not necessary to calibrate volumes V5 and V6 because they are small compared to V4 and W4 and have constant values; an initial measurement will suffice.

The uncertainties of the variables imply a minimum and maximum value that each variable can attain. Likewise, the measured value of $R$ can attain a range of values resulting from varying values of the variables. The equation for $\mathrm{R}$ can be used to determine this range. The minimum value of $R$ is achieved when each term in the numerator has its minimum value and each term in the denominator has its maximum value. Likewise, the maximum value of $R$ is achieved when each term in the numerator assumes its maximum value and each term in the denominator reaches its minimum value. 
The uncertainties of the variables V1, V2, V3, V4, and W4 have been analyzed; and a summary of uncertainty sources and amounts is shown in Appendix A. Statistical data to support this analysis is given in Appendix B. Details of the calculation of the rolamite external volume and volume uncertainty are included in Appendix $C$, along with details of the determination of the volume of the unit handling frame. Measurements of V5 and V6 are described in Appendix D.

\section{Proposed Tolerances}

Tolerances for the volumes based on the uncertainty analysis are proposed below. These values are for tests involving 8 rolamites per test fixture.

Table 1. Proposed Tolerances for Measurement Volumes

\begin{tabular}{|c|c|c|c|}
\hline Volume & Proposed Tolerance & Minimum (mL) & Maximum (mL) \\
\hline V1 & $(3.13 \pm 0.20) \times 10^{-3} \mathrm{~mL}$ & $2.93 \times 10^{-3}$ & $3.33 \times 10^{-3}$ \\
\hline V2 & $21410 \pm 50 \mathrm{~mL}$ & 21360 & 21460 \\
\hline V3 & $1.0667 \pm 0.01 \mathrm{~mL}$ & 1.0567 & 1.0767 \\
\hline V4 & $141.5 \pm 5.0 \mathrm{~mL}$ & 136.5 & 146.5 \\
\hline W4 & $101.4 \pm 6.2 \mathrm{~mL}$ & 95.2 & 107.6 \\
\hline
\end{tabular}

\section{Total Uncertainty of the Process}

The resulting minimum, maximum, and nominal values of the leak rate simulated by the calibration process for a one-hour test are given below.

$$
\begin{aligned}
& \mathrm{R}=\frac{2.93 \times 10^{-3} \times 1.0567(95.2+5.24) \mathrm{mL} / \mathrm{s}}{21460 \times 3600(146.5+5.24)}=2.65 \times 10^{-11} \mathrm{~mL} / \mathrm{s}(\mathrm{min} .) \\
& \mathrm{R}=\frac{3.33 \times 10^{-3} \times 1.0767(107.6+5.24) \mathrm{mL} / \mathrm{s}}{21360 \times 3600(136.5+5.24)}=3.71 \times 10^{-11} \mathrm{~mL} / \mathrm{s}(\max .) \\
& \mathrm{R}=\frac{3.13 \times 10^{-3} \times 1.0667(101.4+5.24) \mathrm{mL} / \mathrm{s}}{21410 \times 3600(141.5+5.24)}=3.15 \times 10^{-11} \mathrm{~mL} / \mathrm{s}(\text { nom. })
\end{aligned}
$$

When only one rolamite is tested per test fixture the tolerance of W4 is changed to $136.4 \pm 5.2 \mathrm{~mL}$. In this case the minimum, maximum, and nominal values are as shown below.

$$
\begin{aligned}
& \mathrm{R}=\frac{2.93 \times 10^{-3} \times 1.0567(131.2+5.24) \mathrm{mL} / \mathrm{s}}{21460 \times 3600(146.5+5.24)}=3.60 \times 10^{-11} \mathrm{~mL} / \mathrm{s}(\min .) \\
& \mathrm{R}=\frac{3.33 \times 10^{-3} \times 1.0767(141.6+5.24) \mathrm{mL} / \mathrm{s}}{21360 \times 3600(136.5+5.24)}=4.83 \times 10^{-11} \mathrm{~mL} / \mathrm{s}(\max .) \\
& \mathrm{R}=\frac{3.13 \times 10^{-3} \times 1.0667(136.4+5.24) \mathrm{mL} / \mathrm{s}}{21410 \times 3600(141.5+5.24)}=4.18 \times 10^{-11} \mathrm{~mL} / \mathrm{s} \text { (nom.) }
\end{aligned}
$$


These values yield an uncertainty range on the leak test measurement of $\pm 18 \%$.

To determine the leak rate for longer tests, divide the above values by the number of hours of testing. For example, for a two-hour test involving 8 rolamites per test fixture, the leak rate simulated by the calibration process would be $1.58 \times 10^{-11} \mathrm{~mL} / \mathrm{s}$.

\section{Accomplishments}

The portion of the measurement uncertainty resulting from the uncertainties of the volumes used for silicone fluid leakage testing has been quantified. Results of the evaluation show that an uncertainty of $\pm 18 \%$ can be achieved at leak rates as small as $1.58 \times 10^{-11} \mathrm{~mL} / \mathrm{s}$ during a twohour test. 
Appendix A

Uncertainty Summary 


\section{UNCERTAINTY SUMMARY}

MEASUREMENT UNC. SOURCES

\section{$5.0 \mu \mathrm{L}$ Syringe (V1)}

Systematic

Difference from $3.13 \mu \mathrm{L}$

Line at $3.0 \mu \mathrm{L}$
MEAS. UNC. AMOUNT

PROPOSED TOLERANCE

$0.00313 \pm 0.00020 \mathrm{~mL}$

Random

Dispensing Variations (11 samples, 3SD)

Balance Uncertainty

Total $\pm 0.000093 \mathrm{~mL}$ $\pm 0.00004 \mathrm{~mL}$

$\pm 0.000133 \mathrm{~mL}$

\section{$21410 \mathrm{~mL}$ Reference Flask (V2)}

$21410 \pm 50 \mathrm{~mL}$

Systematic

Variation in Construction (2 samples) $+31,-31 \mathrm{~mL}$

Random

Balance Uncertainty (Full, $24713 \mathrm{~g}$ )

Balance Uncertainty (Empty, $3603 \mathrm{~g}$ )

Filling Variation

Total $\quad \pm 5 \mathrm{~mL}$ $\pm 2 \mathrm{~mL}$ $\pm 2 \mathrm{~mL}$ $\pm 1 \mathrm{~mL} *$

$1 \mathrm{~mL}$ Syringe (V3)

Systematic

Difference from $1.0667 \mathrm{~mL}$ (4 samples) $+0.0016,-0.0028,-0.0017,+0.0028 \mathrm{~mL}$

Random

Air Bubbles on Teflon

Dispensing Variation (14 samples, 3SD)

Balance Uncertainty (Full, $3.36 \mathrm{~g}$ )

Balance Uncertainty (Empty, $2.28 \mathrm{~g}$ )

Total

$$
\begin{aligned}
& \pm 0.0010 \mathrm{~mL}^{*} \\
& \pm 0.0017 \mathrm{~mL} \\
& \pm 0.0001 \mathrm{~mL} \\
& \pm 0.0001 \mathrm{~mL} \\
& \pm 0.0029 \mathrm{~mL}
\end{aligned}
$$

$1.0667 \pm 0.01 \mathrm{~mL}$ 
Reference Fixture (V4). Test Chamber Assembly, and Test Fixture (W4)

$\begin{array}{ll}\text { Reference (V4) } & 141.5 \pm 5.0 \mathrm{~mL} \\ \text { Test Chamber } & 141.5 \pm 5.0 \mathrm{~mL} \\ \text { Test (1 Rolamite) (W4) } & 136.4 \pm 5.2 \mathrm{~mL} \\ \text { Test (8 Rolamites) (W4) } & 101.4 \pm 6.2 \mathrm{~mL}\end{array}$

Test Chamber Assembly

Systematic

Variation in Construction (36 samples, max.) $\quad \pm 3.84 \mathrm{~mL}$

Random

Balance Uncertainty (Full, $830 \mathrm{~g}$ )

Balance Uncertainty (Empty, $680 \mathrm{~g}$ )

Filling Error (bubbles, etc.)

$\pm 0.00299 \mathrm{~mL}$ $\pm 0.00254 \mathrm{~mL}$

$\pm 0.01 \mathrm{~mL} *$

Total $\quad \pm 0.01553 \mathrm{~mL}$

One Rolamite

Random

Variation in Dimensions

$\pm 0.147 \mathrm{~mL}$

8 Rolamites

Random

Variation in Dimensions

$\pm 1.176 \mathrm{~mL}$

Unit Handling Frame

Random

Uncertainty in Density and Weighing

Part-to-Part Variation (5 samples, 3SD)

$\pm 0.0152 \mathrm{~mL}$ $\pm 0.0045 \mathrm{~mL}$

Total

$\pm 0.0197 \mathrm{~mL}$

*Estimated 
Appendix B

Statistical Data 


\section{STATISTICAL DATA}

Forty-six volumes were calibrated for the leak testing program. Each was given a Calibration Control Number $(\mathrm{CCN})$.

The syringes, flasks, reference fixtures, and test chamber assemblies were calibrated with water. The 5.0- $\mu \mathrm{L}$ syringes were calibrated by weighing the amount of water dispensed from the $3.0-\mu \mathrm{L}$ mark, and the $1.0-\mathrm{mL}$ syringes were calibrated by weighing the amount of water dispensed when the syringes were filled to the stop and emptied. The flasks, reference fixtures, and test chamber assemblies were calibrated by weighing them empty and filled with water. Measurement of the unit handling frame volumes is described in Appendix C. Data from the calibrations are given below.

\section{$\underline{5.0 \mu \mathrm{L} \text { Syringe }(\mathrm{VI})}$}

\begin{tabular}{lllll|llll} 
Trial & \multicolumn{4}{c}{ Volume from $3.0 \mu \mathrm{LLine}\left(10^{-3} \mathrm{~mL}\right)$} & \multicolumn{4}{c}{ Dev. from Avg. $\left(10^{-3} \mathrm{~mL}\right)$} \\
& $\mathrm{CCN}$ & $\mathrm{CCN}$ & $\mathrm{CCN}$ & $\mathrm{CCN}$ & $\mathrm{CCN}$ & $\mathrm{CCN}$ & $\mathrm{CCN}$ & $\mathrm{CCN}$ \\
& $\underline{20997}$ & $\underline{20999}$ & $\underline{21000}$ & $\underline{00872}$ & $\underline{20997}$ & $\underline{20999}$ & $\underline{21000}$ & $\underline{00872}$ \\
1 & 3.1230 & 3.0386 & 3.2082 & 3.1217 & 0.0079 & -0.0617 & 0.0517 & 0.0000 \\
2 & 3.1230 & 3.1050 & 3.1303 & & 0.0079 & 0.0047 & -0.0262 & \\
3 & 3.1270 & 3.1220 & 3.1310 & & 0.0119 & 0.0217 & -0.0255 & \\
4 & 3.0872 & 3.1355 & & & -0.0279 & 0.0352 & & \\
& & & & & & & &
\end{tabular}

\begin{tabular}{ccc} 
& $\begin{array}{c}\text { Volume from } 3.0 \mu \mathrm{L} \text { Line } \\
\left(10^{-3} \mathrm{~mL}\right)\end{array}$ & $\begin{array}{c}\text { Dev. from Avg. } \\
\left(10^{-3} \mathrm{~mL}\right)\end{array}$ \\
\cline { 2 - 3 } 20997 & 3.115 & -0.009 \\
20999 & 3.100 & -0.024 \\
21000 & 3.157 & 0.033 \\
00872 & 3.122 & -0.002
\end{tabular}

Standard Deviation $(11$ trials $)=0.031 \times 10^{-3} \mathrm{~mL}$ 3 Standard Deviations $=0.093 \times 10^{-3} \mathrm{~mL}$

$21410 \mathrm{~mL}$ Reference Flask (V2)

$\begin{array}{ccc}\frac{\mathrm{CCN}}{00829} & \frac{\text { Volume }(\mathrm{mL}) @ 20^{\circ} \mathrm{C}}{21441} & \text { Dev.from } 21410 \mathrm{~mL}(\mathrm{~mL}) \\ 00830 & 21379 & +31\end{array}$


$1 \mathrm{~mL}$ Syringe (V3)

\begin{tabular}{lllll|llll} 
Trial & \multicolumn{5}{c|}{ Volume at Stop $(\mathrm{mL})$} & \multicolumn{4}{c}{ Dev. from Avg. $(\mathrm{mL})$} \\
& $\mathrm{CCN}$ & $\mathrm{CCN}$ & $\mathrm{CCN}$ & $\mathrm{CCN}$ & $\mathrm{CCN}$ & $\mathrm{CCN}$ & $\mathrm{CCN}$ & $\mathrm{CCN}$ \\
& $\underline{21051}$ & $\underline{21052}$ & $\underline{21053}$ & $\underline{20982}$ & $\underline{21051}$ & 21052 & $\underline{21053}$ & $\underline{20982}$ \\
1 & 1.06797 & 1.06511 & 1.06588 & 1.06898 & -0.00035 & 0.00126 & 0.00090 & -0.00056 \\
2 & 1.06850 & 1.06341 & 1.06500 & 1.06968 & 0.00026 & -0.00044 & 0.00002 & 0.00014 \\
3 & 1.06848 & 1.06319 & 1.06407 & 1.06997 & 0.00016 & -0.00066 & -0.00091 & 0.00043 \\
4 & 1.06823 & 1.06368 & & & -0.00009 & -0.00017 & & \\
Avg. & 1.06832 & 1.06385 & 1.06498 & 1.06954 & & & &
\end{tabular}

\begin{tabular}{cc} 
CCN & Volume at Stop $(\mathrm{mL})$ \\
\cline { 2 - 2 } 21051 & 1.0683 \\
21052 & 1.0639 \\
21053 & 1.0650 \\
20982 & 1.0695 \\
Avg. & 1.0667
\end{tabular}

Dev. from Avg. (mL)

0.0016

$-0.0028$

$-0.0017$

0.0028

Standard Deviation (14 trials $)=0.0006 \mathrm{~mL}$

3 Standard Deviations $=0.0017 \mathrm{~mL}$ 
Reference Fixture (V4) and Test Chamber Assembly

\begin{tabular}{lll} 
CCN & Volume (mL) & Dev. from Avg. (mL) \\
\cline { 2 - 3 } 20927 & 144.63 & 3.11 \\
20928 & 140.44 & -1.08 \\
20930 & 137.98 & -3.54 \\
20931 & 140.90 & -0.62 \\
$20933, \# 2$ & 139.94 & -1.58 \\
$20933, \# 3$ & 140.09 & -1.43 \\
$20933, \# 4$ & 144.75 & 3.23 \\
$20933, \# 5$ & 142.79 & 1.27 \\
$20933, \# 6$ & 142.54 & 1.02 \\
$20933, \# 7$ & 140.65 & -0.87 \\
$20933, \# 8$ & 140.22 & -1.30 \\
$20933, \# 9$ & 143.38 & 1.86 \\
$20933, \# 10$ & 145.36 & 3.84 \\
$20933, \# 11$ & 139.40 & -2.12 \\
$20933, \# 12$ & 140.52 & -1.00 \\
$20933, \# 13$ & 143.11 & 1.59 \\
$20933, \# 14$ & 138.29 & -3.23 \\
$20933, \# 15$ & 140.26 & -1.26 \\
$20933, \# 16$ & 140.42 & -1.10 \\
$20933, \# 17$ & 140.31 & -1.21 \\
$20933, \# 18$ & 143.39 & 1.87 \\
$20933, \# 19$ & 141.99 & 0.47 \\
$20933, \# 20$ & 141.53 & 0.01 \\
$20933, \# 21$ & 141.92 & 0.40 \\
$20933, \# 22$ & 142.52 & 1.00 \\
$20933, \# 23$ & 140.83 & -0.69 \\
$20933, \# 24$ & 142.02 & 0.50 \\
$20933, \# 25$ & 139.51 & -2.01 \\
$20933, \# 26$ & 140.99 & -0.53 \\
$20933, \# 28$ & 138.64 & -2.88 \\
$20933, \# 29$ & 144.47 & 2.95 \\
$20933, \# 30$ & 140.55 & -0.97 \\
20934 & 143.27 & 1.75 \\
20935 & 143.18 & 1.66 \\
20936 & 140.41 & -1.11 \\
20937 & 143.48 & 1.96 \\
Avg. & 141.52 & \\
& & \\
& & \\
21 & &
\end{tabular}

Standard Deviation (36 samples) $=1.85 \mathrm{~mL}$

3 Standard Deviations $=5.55 \mathrm{~mL}$ 
Unit Handling Frames

\begin{tabular}{ccc} 
No. & Volume of Unit Handling Frame $(\mathrm{mL})$ & Dev. from Avg. (mL) \\
\cline { 2 - 3 } 2 & 0.1578 & 0.0000 \\
2 & 0.1592 & 0.0014 \\
3 & 0.1555 & -0.0023 \\
4 & 0.1591 & 0.0013 \\
5 & 0.1572 & -0.0006 \\
Avg. & 0.1578 &
\end{tabular}

Standard Deviation of Unit Handling Frames ( 5 samples) $=0.0015 \mathrm{~mL}$

3 Standard Deviations $=0.0045 \mathrm{~mL}$ 
Appendix C

Rolamite and Unit Handling

Frames Volumes and Their Uncertainties 


\section{ROLAMITE AND UNIT HANDLING FRAME VOLUMES AND THEIR UNCERTAINTIES}

Dimensions and dimensional tolerances for the rolamite components were taken from drawings and were used to calculate the external volume and the external volume tolerance of the assembled rolamites. The two rolamites have the same external dimensions.

\begin{tabular}{|c|c|c|c|}
\hline Component & Nom. Volume & Max. Volume & Min. Volume \\
\hline Foot Case & 0.267272 in. $^{3}$ & 0.275161 in. $^{3}$ & 0.260345 in. $^{3}$ \\
\hline Reset Cap & 0.003379 & 0.003680 & 0.003060 \\
\hline Actuate Cap & 0.033292 & 0.034434 & 0.032168 \\
\hline Actuate Pin & 0.000248 & 0.000273 & 0.000273 \\
\hline Actuate Pin & 0.000248 & 0.000273 & 0.000273 \\
\hline Ball & $\underline{0.000052}$ & $\underline{0.000056}$ & $\underline{0.000048}$ \\
\hline Rolamite & 0.304895 in. $^{3}$ & $0.313877 \mathrm{in}^{3}$ & 0.296167 in. $^{3}$ \\
\hline Rolamite & $4.9963 \mathrm{~mL}$ & $5.1435 \mathrm{~mL}$ & $4.8533 \mathrm{~mL}$ \\
\hline
\end{tabular}

The volume and volume tolerance of the rolamites is, therefore, $4.996 \mathrm{~mL} \pm 0.147 \mathrm{~mL}$.

The average volume of the unit handling frame was determined by averaging the volumes of five frames. The volume of the frame was determined by dividing the weight by the density of the wire material. The uncertainty in the weighing of the frame was $\pm 0.4037 \mathrm{mg}$. The density of the wire material was determined by measuring the mass, length, and diameter of a small section of the wire and calculating the density using the formula $d=m / \pi(d / 2)^{2} l$, where $m$ is the mass, $d$ is the diameter and $l$ is the length. The density of the wire was determined to be $7.822 \mathrm{~g} / \mathrm{cm}^{3}$ and the uncertainty in the density was $\pm 0.688 \mathrm{~g} / \mathrm{cm}^{3}$ so that the uncertainty of the frame volume (weight $1.2341 \mathrm{~g}$ ) was calculated to be $\pm 0.0135 \mathrm{~cm}^{3}$ from the formula

$$
\begin{aligned}
\mathrm{V} & =\frac{\text { mass }}{\text { density }}=\frac{1.2341 \mathrm{~g} \pm 0.000404 \mathrm{~g}}{7.822 \mathrm{~g} / \mathrm{cm}^{3} \pm 0.688 \mathrm{~g} / \mathrm{cm}^{3}} \\
& =0.1578 \mathrm{~cm}^{3} \pm 0.0152 \mathrm{~cm}^{3}
\end{aligned}
$$

The volume of one rolamite is $4.996 \mathrm{~mL}$. Hence, the internal volume of the average test fixture containing one rolamite and one unit handling frame is $141.52 \mathrm{~mL}$ minus $4.996 \mathrm{~mL}$ minus $0.1578 \mathrm{~mL}$, or $136.37 \mathrm{~mL}$.

Eight rolamites displace a volume of $39.97 \mathrm{~mL}$. Thus, the internal volume of the average test fixture containing eight rolamites and one frame is $141.52 \mathrm{~mL}$ minus $39.97 \mathrm{~mL}$ minus $0.1578 \mathrm{~mL}$, or $101.39 \mathrm{~mL}$. 
Appendix D

Measurement of Sample Loop Volume and Evacuated Tube Volume 
The volume of the sample loop was measured prior to installing it in the sampler by filling the sample loop tubing with water and weighing. The weight of the filled tube was subtracted from the dry weight to determine the weight of the water in the tube. This was multiplied by the appropriate density factor to determine the volume, $1.0074 \mathrm{~mL}$.

The volume of the evacuated portion of the sampler was measured with a volumeter and was found to be $5.24 \mathrm{~mL}$. Hence, the volume of the evacuated portion of the sampler exclusive of the sample loop was $4.23 \mathrm{~mL}$. 